\title{
Patterns of protein synthesis in endometrial tissues from ovariectomized rats treated with oestradiol and progesterone
}

\author{
B. Lejeune, F. Lamy*, R. Lecocq*, J. Deschacht and F. Leroy \\ Human Reproduction Research Unit and ${ }^{*}$ Institute for Interdisciplinary Research, \\ School of Medicine, Free University of Brussels, 1000 Brussels, Belgium
}

\begin{abstract}
Summary. Groups of ovariectomized rats were taken as controls or given hormonal treatment mimicking the successive steps in the sequence of ovarian secretions leading to implantation. Total endometrium or separated epithelium and stroma were incubated in vitro with $\left[{ }^{35} \mathrm{~S}\right] \mathrm{methionine}$. Dissolved proteins were submitted to two-dimensional polyacrylamide gel electrophoresis ( $\mathrm{pH}$ range 5-7), followed by autoradiography. Priming with oestradiol ( 2 days) and subsequent treatment with progesterone ( 3 days) enhanced the synthesis of 12 and 14 polypeptides, respectively, which are specific for each of these treatments. Progesterone also suppressed the production of 10 oestrogen-dependent proteins both in the epithelium and the stroma. When an oestrogen-progesterone-oestrogen treatment was given, synthesis of all but 4 of the progesterone-induced polypeptides in the epithelium was inhibited while 5 of the proteins abolished by progesterone in this tissue compartment reappeared. These results are compatible with a mechanism of implantation acting at the epithelial level by lifting of intrauterine inhibition and stimulation by embryotrophic substances.
\end{abstract}

\section{Introduction}

Rat blastocysts can implant only after the rise of oestrogen secretion occurring between Days 3 and 4 of gestation (Psychoyos, 1973). In animals ovariectomized on Day 3 and treated with progesterone, implantation does not take place as long as no oestrogen is provided (McLaren, 1973).

Two explanations for the nidatory action of oestrogen have been proposed: (1) stimulation of the synthesis of specific factors which induce blastocyst activation and attachment, and (2) inhibition of the synthesis of intrauterine substances which prevent implantation. Supporting the first hypothesis are the increased uterine RNA and general protein synthesis on Day 5 (Heald, 1976), the induction of implantation by uterine RNA extracts (Segal, Scher \& Koïde, 1977; Lejeune, Puissant, Camus \& Leroy, 1982b) and the secretion into the uterine lumen of specific proteins at Day 5 (Surani, 1977). On the other hand, stimulation of implantation by actinomycin D (Finn, 1974; Camus, Lejeune \& Leroy, 1979) as well as the inhibitory influence on blastocysts of fluids from uteri of animals with delayed implantation (Psychoyos, 1973; Weitlauf, 1976, 1978; O'Neill \& Quinn, 1981,1983 ), stand in favour of a mechanism acting through release from inhibition.

In rats and mice, implantation depends on a sequence of ovarian secretions (oestrogen, progesterone and oestrogen) of which each component fulfils a particular role (Finn \& Martin, 1974; Leroy, Schetgen \& Camus, 1980). Therefore, the aim of the present study was to analyse changes in the pattern of endometrial protein synthesis in relation to implantation, by experiments mimicking the progestational period (Psychoyos, 1961; Finn \& Martin, 1974), and to study the effects of each of its hormonal components on whole endometrium or on separated epithelium and stroma 


\section{Materials and Methods}

At 2 weeks after ovariectomy groups of $10 \mathrm{Wistar}$ rats (body weight $150 \mathrm{~g}$ ) were taken as controls (Group 1) or given one of the following sequential treatments: $1 \mu \mathrm{g}$ oestradiol-17 $\beta$ daily for 2 days (Group 2); $1 \mu \mathrm{g}$ oestradiol-17 $\beta$ for 2 days, 2 days of rest and $5 \mathrm{mg}$ progesterone per day for 3 days (Group 3); $1 \mu \mathrm{g}$ oestradiol-17 $\beta$ for 2 days, 2 days of rest, $5 \mathrm{mg}$ progesterone for 3 days and $50 \mathrm{ng}$ oestradiol-17 $\beta$ in the evening of the third day of progesterone treatment (Group 4).

Animals were killed $24 \mathrm{~h}$ (Groups 2 and 3) or $15 \mathrm{~h}$ (Group 4) after the end of hormonal treatment. Uteri from Groups 1 and 2 were slit lengthwise and total endometrium was scraped off with a scalpel. Pure epithelium was squeezed out of uterine horns from progesterone-treated animals (Groups 3 and 4) by use of forceps (Bitton Casimiri, Rath \& Psychoyos, 1977). The horns were then opened longitudinally and the remaining stroma was removed by scraping.

The endometrial tissues were incubated for $15 \mathrm{~min}$ at $37^{\circ} \mathrm{C}$ in $10 \mathrm{ml} \mathrm{Krebs}$-Ringer-bicarbonate solution (KRB) (Krebs, 1950) supplemented with $20 \mathrm{mg}$ collagenase (clostridiopeptidase A; Böehringer, Mannheim). After three washes in KRB the tissues were centrifuged for $10 \mathrm{~min}$ at 200 $g$ and incubated for $8 \mathrm{~h}$ at $37^{\circ} \mathrm{C}$ under an atmosphere of $5 \% \mathrm{CO}_{2}-95 \% \mathrm{O}_{2}$ in $1 \mathrm{ml} \mathrm{Eagle's} \mathrm{medium}$ (Flow Labs, Brussels) supplemented with $500 \mu \mathrm{Ci}\left[{ }^{35}\right.$ S]methionine (sp. act. $800 \mathrm{Ci} / \mathrm{mmol}$ : Amersham, Belgium). Protein sample preparations, measurements of incorporated radioactivity, two-dimensional gel electrophoresis according to O'Farrell (1975) and autoradiography, were performed as described in a previous study (Lejeune, Lecocq, Lamy \& Leroy, 1982a).

\section{Results}

Three separate experiments, each including the four groups described above, gave almost identical results indicating that the effects of the different hormone treatments were reproducible. Prominent modifications of polypeptide synthesis are listed in Table 1. Approximate molecular weights and isoelectric points under the adopted working conditions were calculated as previously described (Lejeune et al., 1982a). Oestradiol given alone for 2 days (Group 2) promoted or increased the synthesis of 12 polypeptides (numbered from 1 to 12 on Pl. 1, Fig. 2) of relatively low molecular weight (23000-55000) which were not detectable in the endometrium of ovariectomized rats

\section{PLATES 1-3}

Autoradiographic patterns of two-dimensional electrophoretic separation of $\left[{ }^{35} \mathrm{~S}\right] \mathrm{methionine-}$ labelled proteins, extracted from rat endometrium sequentially treated with oestradiol, progesterone and oestradiol. Polypeptides of which the synthesis is either markedly enhanced or reduced as compared to the previous treatment group are indicated by arrows or pointed triangles, respectively.

\section{PLATE 1}

Fig. 1. Total endometrium from ovariectomized animals (Group 1).

Fig. 2. Total endometrium from animals primed with oestradiol (Group 2).

\section{PLATE 2}

Fig. 3. Luminal epithelium from animals treated with oestradiol plus progesterone (Group 3). Fig. 4. Endometrial stroma from animals treated with oestradiol plus progesterone (Group 3).

\section{PLATE 3}

Fig. 5. Luminal epithelium from animals treated with oestradiol, progesterone and oestradiol (Group 4).

Fig. 6. Endometrial stroma from animals treated with oestradiol, progesterone and oestradiol (Group 4). 
PLATE 1

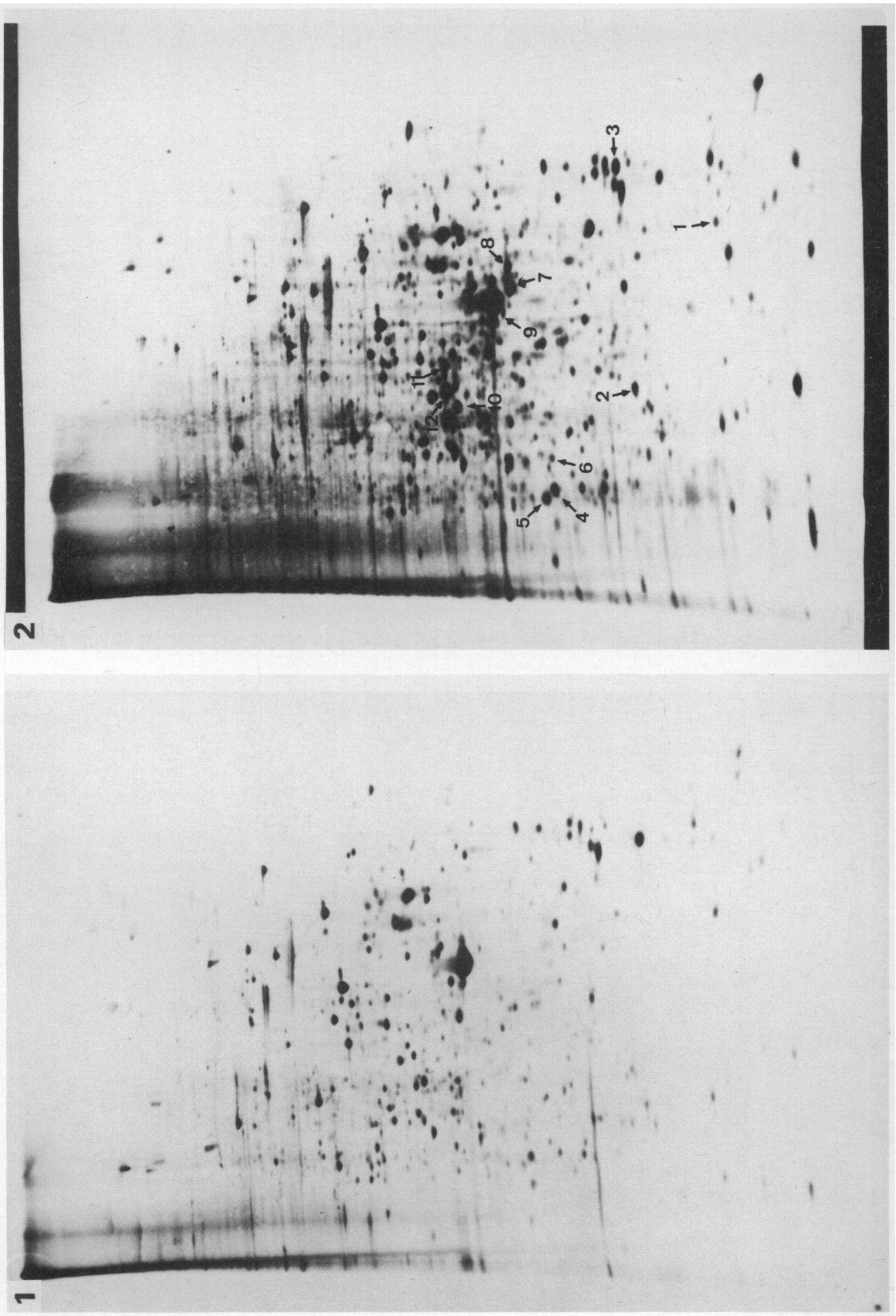



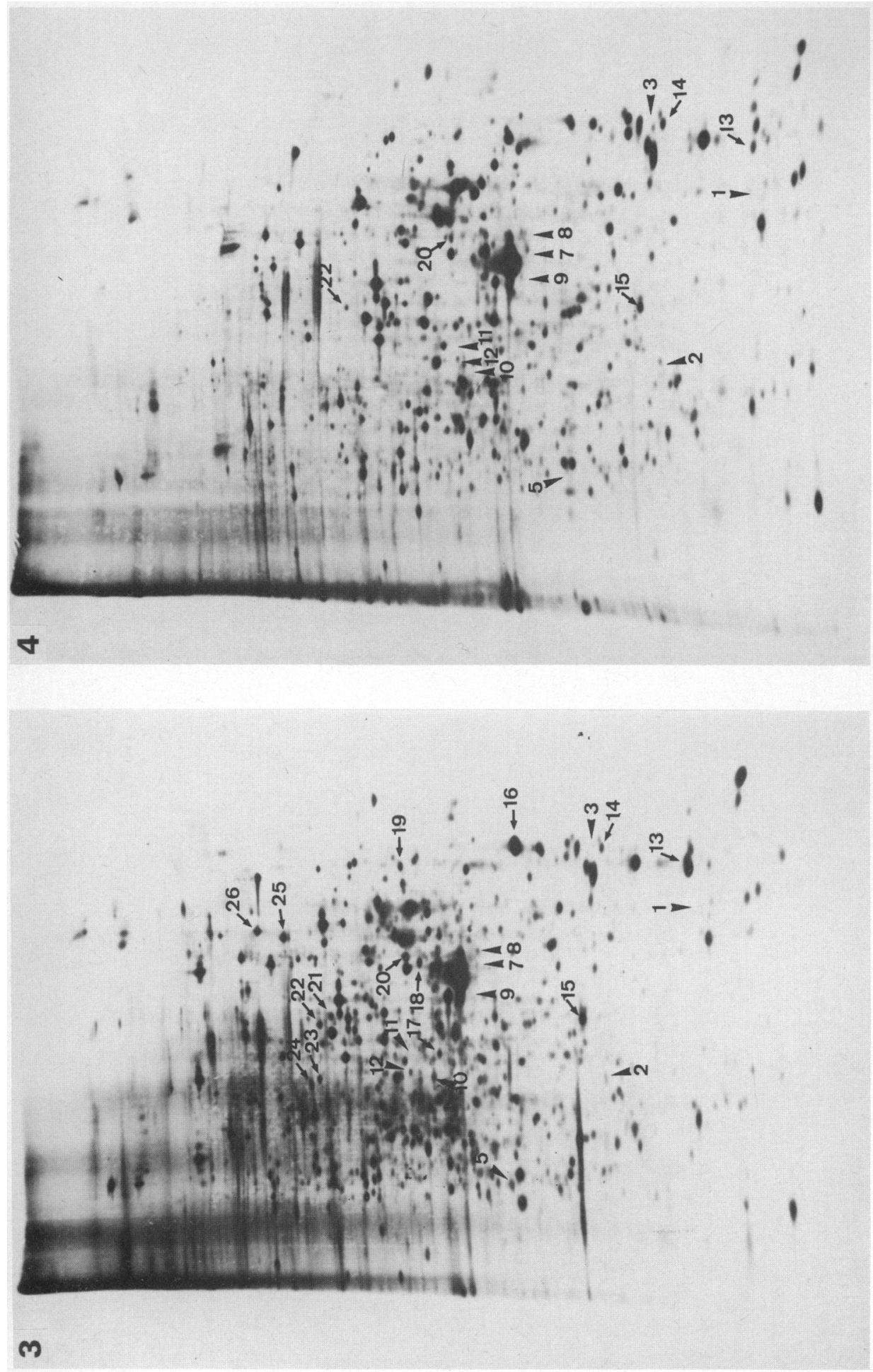

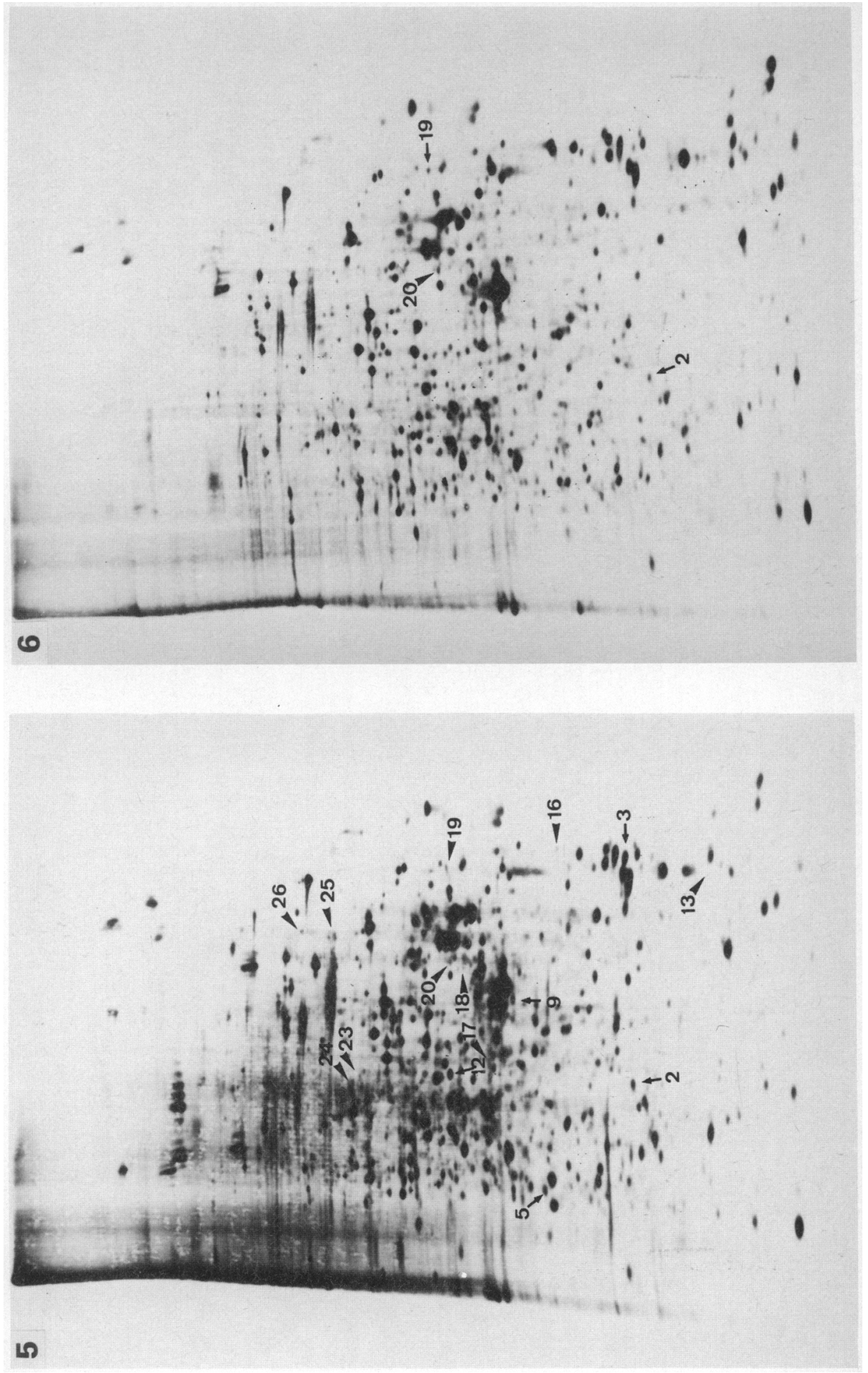
Table 1. Analysis of the effects of oestradiol $\left(\mathrm{E}_{2}\right)$ and progesterone $(\mathrm{P})$ on endometrial protein synthesis by two-dimensional electrophoresis

\begin{tabular}{|c|c|c|c|c|c|c|c|}
\hline \multirow[b]{3}{*}{$\begin{array}{l}\text { Polypeptide } \\
\text { no. }\end{array}$} & \multirow[b]{3}{*}{$\begin{array}{l}\text { Approximate } \\
\text { mol. wt }\left(\times 10^{-3}\right)\end{array}$} & \multirow{3}{*}{$\begin{array}{l}\text { Approx. } \\
\text { isoelectric } \\
\text { point }\end{array}$} & \multicolumn{5}{|c|}{ Treatment groups } \\
\hline & & & \multirow{2}{*}{$\frac{\text { Group } 2\left(\mathrm{E}_{2}\right)}{\text { Total }}$} & \multicolumn{2}{|c|}{ Group $3\left(E_{2}+P\right)$} & \multicolumn{2}{|c|}{ Group $4\left(E_{2}+P+E_{2}\right)$} \\
\hline & & & & Epithelium & Stroma & Epithelium & Stroma \\
\hline 1 & 22 & $5 \cdot 67$ & + & - & - & 0 & 0 \\
\hline 2 & 29 & 6.22 & + & - & - & + & + \\
\hline 3 & 30 & $5 \cdot 40$ & + & - & - & + & 0 \\
\hline 4 & 36 & 6.62 & + & 0 & 0 & 0 & 0 \\
\hline 5 & 37 & 6.62 & + & - & - & + & 0 \\
\hline 6 & 37 & 6.37 & + & 0 & 0 & 0 & 0 \\
\hline 7 & 43 & 5.88 & + & - & - & 0 & 0 \\
\hline 8 & 43 & 5.76 & + & - & - & 0 & 0 \\
\hline 9 & 44 & 6.00 & + & - & - & + & 0 \\
\hline 10 & 52 & $6 \cdot 33$ & + & - & - & 0 & 0 \\
\hline 11 & 55 & $6 \cdot 14$ & + & - & - & 0 & 0 \\
\hline 12 & 55 & $6 \cdot 28$ & + & - & - & + & 0 \\
\hline 13 & 23 & 5.55 & & + & + & - & 0 \\
\hline 14 & 30 & $5 \cdot 50$ & & + & + & 0 & 0 \\
\hline 15 & 32 & $6 \cdot 14$ & & + & + & 0 & 0 \\
\hline 16 & 35 & 5.48 & & + & 0 & - & 0 \\
\hline 17 & 49 & $6 \cdot 20$ & & + & + & - & 0 \\
\hline 18 & 53 & 5.86 & & + & 0 & - & 0 \\
\hline 19 & 54 & 5.44 & & + & 0 & - & + \\
\hline 20 & 55 & 5.86 & & + & + & - & - \\
\hline 21 & 72 & $6 \cdot 10$ & & + & 0 & 0 & 0 \\
\hline 22 & 75 & $6 \cdot 10$ & & + & + & 0 & 0 \\
\hline 23 & 80 & $6 \cdot 24$ & & + & 0 & - & 0 \\
\hline 24 & 80 & $6 \cdot 24$ & & + & 0 & - & 0 \\
\hline 25 & 90 & 5.80 & & + & 0 & - & 0 \\
\hline 26 & 105 & 5.78 & & + & 0 & - & 0 \\
\hline
\end{tabular}

For easy comparison, polypeptides are classified by increasing molecular weight in 2 successive series (1-12 and 13-26).

+ , newly appearing or markedly increased synthesis; -, disappearing or markedly reduced synthesis; 0 , not modified by comparison with previous treatment group.

(Group 1). No protein synthesized by unstimulated endometrium disappeared after oestrogen treatment. By contrast, 3 days of progesterone treatment given after oestradiol priming followed by 2 days of rest (Group 3) caused the disappearance of 10 of the oestrogen-stimulated polypeptides (Nos 1, 2, 3, 5, 7, 8, 9, 10, $11 \& 12$ on Pl. 2, Figs $3 \&$ \&) in the epithelium as well as in the stroma. However, progesterone induced the synthesis of 14 new polypeptides (numbered from 13 to 26 on Pl. 2, Fig. 3) in the epithelium (mol. wt 23 000-105 000) amongst which 6 were also detected in the stromal fraction (Nos 13, 14, 15, 17, 20 \& 22 on Pl. 2, Fig. 4). Injection of $50 \mathrm{ng}$ oestradiol on the 3rd day of progesterone treatment (Group 4) resulted in the inhibition of all but 4 (Nos 14, 15, 21 \& 22) of the polypeptides induced by progesterone in the epithelial compartment. Moreover, 5 epithelial proteins (Nos 2, 3, 5, 9 \& 12) for which synthesis was abolished by progesterone (Group 3) reappeared (Pl. 3, Fig. 5). In the stroma, however, very few differences were observed: spots 2 and 19 were increased while No. 20 was decreased (PI. 3, Fig. 6).

\section{Discussion}

Oestrogen administration to ovariectomized or immature animals entails notable amplification of protein synthesis by uterine cells while many enzyme activities become increased at this level (see 
Segal et al., 1977). Therefore, it is not surprising that after 2 days of priming with oestradiol we could observe the synthesis of at least 12 peptides which were not detectable in the endometrium of ovariectomized rats.

Much work has been devoted to the identification of protein synthesis which is specifically elicited through oestrogen treatment. These studies, however, cannot be validly compared to our results since they mostly deal with the so-called 'induced protein' (IP) which can only be detected during the first few hours of oestrogen action (De Angelo \& Gorski, 1970; Cohen \& Hamilton, 1975). Identification of acidic nuclear proteins, the synthesis of which is specifically stimulated by oestradiol, is likewise related to durations of hormone action much shorter than in the present work (Barker, 1971; Hamilton, 1971). Also the analysis of uterine protein synthesis by a two-dimensional method as carried out by Korach, Harris \& Carter (1981) did not extend beyond $7 \mathrm{~h}$ after oestradiol administration.

By use of monodimensional gel electrophoresis after the same priming treatment with oestradiol as in our experiments, Surani (1977) was able to show that the profile of uterine protein synthesis closely resembles that observed at normal pro-oestrus. Labelled proteins of high molecular weight (80000-135000) are mainly represented under such conditions. The absence of ovariectomized controls in this study makes it difficult to draw a close comparison with our data. However, the relative paucity of labelled proteins of high molecular weight in our experiments may be explained by the more denaturing technical conditions that we used, i.e. treatment with $8 \mathrm{M}$-urea and mercaptoethanol.

Compared to the effects of oestrogen given for 2 days, long-term administration of progesterone results in relatively low radiolabelling of rat uterine luminal proteins (Surani, 1977). When injected at different times after priming with oestradiol, a single dose of progesterone is able to inhibit overall uterine protein synthesis within 2 h (Trams, Brewitt, Möllmann \& Maas, 1973). Similar antagonistic effects of progesterone administration were found in relation to several specific responses to oestradiol. Pretreatment with progesterone inhibits subsequent oestrogen-dependent induced protein synthesis (Bhakoo \& Katzenellenbogen, 1977). Given after priming with oestradiol, progesterone prevents the oestrogen-receptor replenishment which is normally induced by oestrogen (Hsueh, Peck \& Clark, 1976). However, oestrogen-stimulated synthesis of sulphonated glycoproteins in the luminal epithelium of rat uterus becomes arrested through subsequent progesterone administration (Takata \& Terayama, 1979). Our observation that progesterone treatment inhibits the production of most polypeptides which are induced by priming with oestradiol is consistent with the above-mentioned antagonistic effects. However, under our experimental conditions, which closely mimic the progestational hormonal sequence (Finn \& Martin, 1974), progesterone redirected endometrial protein synthesis by initiating the appearance of 14 new peptides in the epithelium and 6 in the stroma. Only 2 labelled compounds remained common to oestradiol priming and subsequent progesterone stimulation. Our results show that progesterone tends to switch endometrial protein synthesis from oestrogen-dependent low molecular weight substances to the production of bigger polypeptides. This observation is compatible with the hypothesis that progesterone prepares the endometrium for blastocyst implantation by first eliciting gene activation, transcription and translation of chromosomal information (O'Malley, 1971).

The addition of $50 \mathrm{ng}$ oestradiol to oestrogen and progesterone priming (Group 4) suppressed the production of 10 epithelial peptides and 1 stromal peptide. Since small amounts of oestrogen are able to trigger the attachment of delayed blastocysts (Psychoyos, 1973), these changes would support the theory that implantation occurs after the disappearance of intrauterine inhibitory factors (Psychoyos, 1973; Finn, 1974; Leroy et al., 1980). No synthesis of any new peptide was observed in Group 4 animals. Therefore, our results tend to contradict the proposition that blastocyst activation depends on the production of a molecule which inactivates inhibitory proteins (Weitlauf, 1976). Such a factor, however, might originate from the embryos themselves (O'Neill \& Quinn, 1981, 1983). In a recent study using bidimensional mapping it was found that in the endometrium of pregnant rats killed at the time of implantation (Day 5) no unique protein appears while several peptides are no longer synthesized (Mulholland \& Villee 1984 ), 
It is possible that implantation is related to intrauterine release of embryotrophic substances (Aitken, 1977; Surani, 1977). In this context we found that 4 proteins synthesized in the progesterone-dominated epithelium (Group 3) remain present after 'nidatory' oestrogen action (Group 4). In view of their similar molecular weights (30000-75000), these peptides might belong to the group described by Surani (1977) in uterine flushings obtained at Day 5 of pregnancy or after combined progesterone and oestradiol treatment. These compounds, which are already synthesized in the progesterone-treated epithelium, as shown in our work, might be secreted into the uterine lumen only after treatment with 'nidatory' oestrogen. Since flushing has been shown to disrupt the endometrial lining it is also possible that more intracellular proteins are liberated as a consequence of increased damage which occurs when tight closure of the uterine lumen has been completed through luteal oestrogen action (Martin, 1984; Milligan \& Martin, 1984).

Five proteins (Nos 2, 3, 5, 9 \& 12) (mol. wt $29000-55000$ ) induced by oestradiol given alone but disappearing when there is additional progesterone treatment are again synthesized after giving 'nidatory' oestrogen. These findings are consistent with results showing that implantation of delayed blastocysts can be obtained by injecting uterine RNA extracts from oestrogen-treated ovariectomized rats (Segal et al., 1977; Lejeune et al., 1982b).

Very few modifications occur in the stroma while nearly all appearing and disappearing polypeptides are observed in the uterine epithelium after 'nidatory' oestrogen administration. Such observations support the theory that luteal oestrogens are mainly acting at the level of the epithelial cells (Finn, 1974; Leroy et al., 1980) in the triggering of implantation.

On the whole, our data are compatible with the hypothesis that implantation is contingent upon 2 chains of transcriptional and translational events (Leroy et al., 1980), i.e. (1) intraluminal secretion of inhibitory proteins controlled by progesterone and of which the synthesis can be suppressed by luteal oestrogen or by actinomycin D, and (2) production of embryotrophic proteins (perhaps already present in ovariectomized animals) which is enhanced by oestrogen at pro-oestrus and able to overcome the repressive effects of progesterone-dependent inhibitors if overstimulated by exogenous uterine RNA.

This work was supported by the Belgian F.R.S.M. and by a grant from the Ministry of Scientific Policy ("Actions Concertées"). F.L. is "Maître de Recherches" at the Belgian F.N.R.S.

\section{References}

Aitken, R.J. (1977) Changes in protein content of mouse uterine flushings during normal pregnancy and delayed implantation, and after ovariectomy and oestradiol administration. J. Reprod. Fert. 50, 29 36.

Barker, K.L. (1971) Estrogen-induced synthesis of histones and a specific non histone protein in the rat uterus. Biochemistry, N.Y. 10, 284-291.

Bhakoo, H.S. \& Katzenellenbogen, B.S. (1977) Progesterone antagonism of oestradiol-stimulated uterine "induced protein" synthesis. Molec. cell. Endocr. 8, $105-120$.

Bitton Casimiri, V., Rath, N.C. \& Psychoyos, A. (1977) A simple method for separation and culture of rat uterine epithelial cells. J. Endocr. 73, 537-538.

Camus, M., Lejeune, B. \& Leroy, F. (1979) Induction of implantation in the rat by intraparametrial injection of actinomycin D. Biol. Reprod. 20, 1115-1118.

Cohen, M.E. \& Hamilton, T.H. (1975) Sequential stimulation of synthesis of two specific cytoplasmic proteins in early estrogen action. Biochem. Biophys. Res. Commun. 64, 633-639.
De Angelo, A.B. \& Gorski, J. (1970) Role of RNA synthesis in the estrogen-induction of a specific uterine protein. Proc. natn. Acad. Sci. U.S.A. 66, 693700.

Finn, C.A. (1974) The induction of implantation in mice by actinomycin D. J. Endocr. 60, 199-200.

Finn, C.A. \& Martin, L. (1974) The control of implantation. J. Reprod. Fert. 39, 195-206.

Hamilton, T.H. (1971) Effects of sexual steroid hormones on genetic transcription and translation. In Basic Actions of Sex Steroids on Target Cells, pp. 56-92. Eds P. O. Hubinont, F. Leroy \& P. Galand. Karger, Basel.

Heald, P.J. (1976) Biochemical aspects of implantation. J. Reprod. Fert., Suppl. 25, 29-52.

Hsueh, A.J.W., Peck, E.J., Jr \& Clark, J.H. (1976) Control of uterine estrogen receptor levels by progesterone. Endocrinology 98, 438-444.

Korach, K.S., Harris, S.E. \& Carter, D.B. (1981) Uterine proteins influenced by estrogen exposure. Analysis by two-dimensional gel electrophoresis. Molec. cell. Endocr. 21, 243-254 
Krebs, H.A. (1950) Body size and tissue respiration. Biochem. Biophys. Acta 4, 249-269.

Lejeune, B., Lecocq, R., Lamy, F. \& Leroy, F. (1982a) Changes in the pattern of endometrial protein synthesis during decidualization in the rat. J. Reprod. Fert. 66, 519-523.

Lejeune, B., Puissant, F., Camus, M. \& Leroy, F. (1982b) Induction of implantation in the rat by intraparametrial injection of uterine RNA from oestrogen-treated animals. J. Endocr. 93, 397-402.

Leroy, F., Schetgen, G. \& Camus, M. (1980) Initiation of implantation at the subcellular level. In BlastocystEndometrium Relationships, pp. 200-215. Eds F. Leroy, C. A. Finn \& A. Psychoyos. Karger, Basel.

Martin, L. (1984) On the source of uterine 'luminal fluid' proteins in the mouse. J. Reprod. Fert. 71, 73-80.

McLaren, A. (1973) Blastocyst activation. In The Regulation of Mammalian Reproduction, pp. 321-328. Eds S. J. Segal, R. Crozier, P. A. Corfman \& P. G. Condliffe. Charles C. Thomas, Springfield.

Milligan, S.R. \& Martin, L. (1984) The resistance of the mouse uterine lumen to flushing and possible contamination of samples by plasma and interstitial fluid. J. Reprod. Fert. 71, 81-87.

Mulholland, J. \& Villee, C.A., Jr (1984) Proteins synthesized by the rat endometrium during early pregnancy. J. Reprod. Fert. 72, 395-400.

O'Farrell, P.H. (1975) High resolution two-dimensional electrophoresis of proteins. J. biol. Chem. 250, 40074021.

O'Malley, B. (1971) The action of progesterone at the cellular level. Research in Reproduction 3, 3-4.

O'Neill, C. \& Quinn, P. (1981) Interaction of uterine flushings with mouse blastocysts in vitro as assessed by the incorporation of $\left[{ }^{3} \mathrm{H}\right]$ uridine. J. Reprod. Fert. 62, 257-262.

O'Neill, C. \& Quinn, P. (1983) Inhibitory influence of uterine secretions on mouse blastocysts decreases at the time of blastocyst activation. J. Reprod. Fert. 68, 269-274.

Psychoyos, A. (1961) La nidation de la rate et la dose d'oestrogènes nécessaire. C.r. hebd. Séanc. Acad. Sci. Paris D 253, 1616-1617.

Psychoyos, A. (1973) Hormonal control of ovo-implantation. Vitams Horm. 31, 201-256.

Segal, S.J., Scher, W. \& Koïde, S.S. (1977) Estrogens, nucleic acids and protein synthesis in uterine metabolism. In Biology of the Uterus, pp. 139-201. Ed. R. M. Wynn. Plenum Press, New York.

Surani, M.A.H. (1977) Radiolabelled rat uterine luminal proteins and their regulation by oestradiol and progesterone. J. Reprod. Fert. 50, 289-296.

Takata, K. \& Terayama, H. (1979) Estrogen-dependent and progesterone-arrested synthesis and secretion of sulfated glycoproteins in luminal epithelia of rat uteri. Biochim. Biophys. Acta 586, 594-607.

Trams, G., Brewitt, H., Möllmann, H. \& Maas, H. (1973) Effect of progesterone on RNA and protein synthesis in the rat uterus. Acta endocr., Copenh. 73, 740-750.

Weitlauf, H.M. (1976) Effect of uterine flushings on RNA synthesis by "implanting" and "delayed implanting" mouse blastocysts in vitro. Biol. Reprod. 14, 566-571.

Weitlauf, H.M. (1978) Factors in mouse uterine fluid that inhibit the incorporation of $\left[{ }^{3} \mathrm{H}\right]$ uridine by blastocysts in vitro. J. Reprod. Fert. 52, 321-325.

Received 15 May 1984 